\title{
Modern Technical Education in Northeast China and its Influence on the Industrial Development of China Since 1932
}

\author{
Wentao Zhao ${ }^{1, *}$
}

\author{
${ }^{I} M S c$ in Social and Public Policy, Cardiff University \\ Corresponding author. Email: baiduren9255@163.com
}

\begin{abstract}
This article concludes the industrial development of China since the puppet Manchurian period and the influence of technical education within this development. Japanese imperialism gradually established various colonial schools at all levels by formulating a series of colonial educational policies, and firmly controlling the educational rights in Northeast China. Furthermore, it argues that amongst all of the aspects of educational development during the puppet Manchurian period, the introduction and development of the apprenticeship system has most greatly impacted industries in Northeast China. From the perspective of dynamic changes, during the Ninth Five-Year Plan (1996 2000) and the Tenth FiveYear Plan (2001 2005), the relative advantages of industrialization of the three northeastern provinces continued to be lost and even turned into relative disadvantages. The guidance of public policies is an important aspect of this industrial decrease, especially the deviation from the implementation of industrial support policies and the lack of vocational educational support.
\end{abstract}

Keywords: Northeast China, puppet Manchuria, industrial development, technical education, apprenticeship

\section{INTRODUCTION}

In the early days of the founding of the People's Republic of China, the Northeast region absorbed and digested its industrial heritage, quickly restoring and developing the production capacity after the war, whilst laying the foundations for human resources. At that time, there was no such situation in other parts of China. In addition, the geographical advantages of the Northeast in terms of energy and agricultural production, as well as the relatively safe geographical conditions in the early days of the founding of the People's Republic of China, have all contributed towards giving the Northeast extremely important industrial and agricultural status. It became an important production base for China's industrial construction at that time. The function of the Northeastern industry has made contributions to China and also leaves a strong influence on successive generations. Amongst all of the aspects of educational development during the puppet Manchurian period, the development of the 'apprenticeship' system has impacted the industries in Northeast China most of all. From the Republic of China to the puppet Manchurian period, then stepping into the People's Republic of China, the apprenticeship system experienced a period of great change in both the political economy and production methods which served both economic and educational functions. As result of transformations under the influence of social changes, the gradual transition of the apprenticeship from the feudal patriarchal norms to the legal system proved to be positive influences which laid the foundations of industrial development.

\section{INDUSTRIAL DEVELOPMENT IN NORTHEAST CHINA UNDER THE PUPPET MANCHUKUO AND ITS EDUCATION POLICIES, 1932-1945}

After the Japanese invasion of Manchuria and the founding of puppet Manchukuo in 1932, the Japanese exploitation in the economic development of the Northeast China was part of the movements in Second Sino-Japanese War (1937-1945), the oriental warfares of the World Anti-Fascist War. In the struggle for the economy, Japan continuously adjusted its economic control policies according to its own needs, and under the slogans of "coexistence and co-prosperity" and "Japan 
and Manchuria", turning the Manchukuo into a vassal of the Japanese economy. Under the Japanese monopoly, Liaoning Heavy Industry went through a path of abnormal development. Shenyang was designated as part of the military industrial land, and Shenyang became an industrial center of the Puppet Manchukuo. After 1937, the combination of "Manchuria Heavy Industry Development Co., Ltd." and the "Five-Year Economic Plan" made materials, funds, and labor more concentrated in the heavy industry sector. By 1941, "Man Yee" controlled about $80 \%$ of the coal industry, steel smelting industry, and light metal industry in the Northeast, and $100 \%$ of the aircraft and automobile manufacturing industries, and the main components of coal, steel and light metals. [1] The origin is in Liaoning. In essence, "the puppet industry" controlled Liaoning Heavy Industry. The advanced growth of the energy and raw materials industry broke the economic development. This kind of economic "development" originated from plunder, because it violates objective economic laws, and it is bound to encourage economic chaos and contradictions.

After the outbreak of the Pacific War, Japan's plundering of war resources entered a more frenzied stage. They continued to implement all the industries that are easy to develop but necessary in the Northeast, try their best to develop in the Northeast, especially basic industries such as iron, coal, petroleum, and electricity. The industry continued to substantially increase the production index of war resources such as steel, coal, liquid fuels, light metals, non-ferrous metals, and agricultural products. During this period, Japan gradually lost on the battlefield. As a result, the degree of Japanese and puppet economic control continued to deepen, and the extent of plundering increased unprecedentedly, causing the Puppet Manchurian industry to almost completely collapse. The production of Liaoning's heavy industry also shifted from a vicious expansion to a depressed ceasefire, and the consequences of the abnormal development began to fully manifest.

In addition to the vicious expansion of heavy industry itself, the abnormal development of Liaoning's heavy industry also manifested in a kind of 'destructive production' with no long-term planning. Although steel production targets were expanding, they were difficult to achieve. In order to increase production, the Japanese invaders used various ways of exploiting mineral resources. In the destructive production process, Japan practiced technology monopolies and China lacked technical talents. The completion of Fengxi Industrial Zone doubled the total industrial volume of Shenyang. Due to its large scale and complete supporting facilities, Fengxi Industrial Zone was called "Oriental Ruhr". However, the Fengxi Industrial Zone was the same as other industrial and mining enterprises. The main industrial technology was completely controlled by the Japanese, and the Chinese were just cheap laborers. In
$1944,92 \%$ of the machine tools required by Fengtian were shipped from Japan, and $84 \%$ of the precision machinery was also supplied by Japan. [2] Fengtian and even the Northeast had not formed independent production. The complete mechanical industry system and the lack of technology also made it lose the ability to develop independently. In addition, in the management mechanism, in the industrial structure, and in the source of capital, the trend of abnormal development was everywhere.

The status of the heavy industrial center in the Northeast region benefits from a strong reserve of industrial and technical talents and a developed education system, including higher education institutions and vocational and technical education institutions. During the period of the Puppet Manchukuo, the authorities introduced a new school system and industrial education, which shortened the duration of education and implemented comprehensive vocational education, to plunder the resources of the Northeast. For elementary school students, a certain understanding of vocational education was required. [3] Actually, they changed the nature of the original secondary education, focusing on industry and practical education. The duration of secondary education and higher education was shortened, and the entire school system was reduced by three years in comparison with the original school system. At that time, the basic structure of the Japanese school system was 18 years. Compared with Japan, the new school system was five years shorter. The reduction in study time allowed young and middle-aged people to quickly engage in work.

In addition, the vocational education received enabled young and middle-aged people to gain skills and start to work. Many of the contents of the industrial education that young adults received were skills that front-line workers needed to master, with less theoretical knowledge taught, most of their time was spent on site labor. In this way, young and middle-aged people accumulated work experience earlier and became reserve first-line technical talents for the development of heavy industry in the three northeast provinces after the founding of the People's Republic of China.

During the puppet Manchukuo period, Japanese imperialism gradually established various colonial schools at all levels by formulating a series of colonial educational policies, and firmly controlling the educational rights in Northeast China. Until the Japanese surrendered in 1945, the higher education of Northeast China has been dominated by engineering, medical, and agricultural majors. [4] Schools had limited space and quotas. Some vocational and technical universities were set up, such as Datong University, the Japan Preparatory School, the Shinkyo University of Science and Technology, and the national Fengtian Agricultural University. Universities had a lot of cooperation between 
each other mainly including agricultural, political and legal, medical and industrial universities. In this era, higher education spread scientific knowledge, cultivated the students' sense of social responsibility, and promoted their participation in the national economy and social culture.

On the other hand, higher education promoted the human capital of Northeast China and produced educational services with resources and technology beneficial to individuals and society. [5] During the implementation of the "new school system", the Puppet Manchurian government strengthened the study of spirit and self-cultivation courses and made industrial education and physical training the focus of educational content. They had set up practical courses and industrial schools focused on agriculture, medicine, and industry, together with the normal educational stages. The factories set up a separate education to train qualified teachers. [6] These measures, in the puppet Manchu period, systematically trained students of all ages with a certain degree of industrial technology and knowledge. The combination of production and learning formed some advanced concepts of industrial development, which was meaningful for both theory and practice.

\section{THE INTRODUCTION OF APPRENTICESHIP SYSTEM}

Amongst all of the aspects of educational development during the puppet Manchurian period, the introduction and development of the 'apprenticeship' system has most greatly impacted industries in Northeast China. Apprenticeship is a talent training model, and technical skills are passed on and carried forward through the link of "master-apprentice", playing a pivotal role in all periods of human history. Although the apprenticeship also presents various forms and characteristics due to differences in the region, time, and culture, its essence exists as a form of accumulation and transmission of human knowledge and skills.

After the Opium War in 1840, Western adventurers opened the door to China's seclusion, leading to the Westernization Movement and the wave of industrial salvation in the late Qing Dynasty. There were a large number of emerging industries and businesses in cities such as Shanghai, Beijing, and Guangzhou. The original apprenticeship was based on the number of apprentices. But the quality of training could no longer adapt to and meet the needs of large-scale production and management of emerging industries and commerce, so the trainee system emerged. Developed from traditional handicraft industry to the machine industry, this trainee system formed the main mode of employment and economic benefits, a system of unified management and training of apprentices as a gathering mechanism. Although the trainee system started late and developed slowly, it was born in the late Qing Dynasty and the early
Republic of China. The exploration of the trainee system popular in the Republic of China was a useful revolution in apprenticeship. It can be called the earliest modern apprenticeship exploration in China, or an early prototype of modern apprenticeships.

The factory apprenticeship during the Republic of China was the result of transformations under the influence of social changes. The promulgation of relevant laws and regulations represents the gradual transition of the apprenticeship from the feudal patriarchal law to the legal system, though it demonstrated advantages and disadvantages throughout the period. [7] As early as 1915, the trainee system had become an effective training model for new technical talents and formed a considerable scale. From apprentices to trainees, not only was the name changed, but it also marked the abolition of the patriarchal mentorship relationship under the old apprenticeship system. [8] National capitalists and foreign businessmen recruited a certain number of trainees to cultivate business knowledge. In the management assessment, the trainees who had completed their studies would be directly promoted to company employees, and those who failed the assessment will be eliminated.

Japan's apprenticeship system reached its peak in the Edo period. It was very friendly to both businessmen and craftsmen at that time. Through the guidance of cultural knowledge, training of basic business skills, and ideological education for apprentices, it could promote the comprehensive and scientific development of apprenticeships. Because apprentices generally studied with businessmen and handicraftsmen, they basically took commercial activities and production needs as their learning direction, which was very utilitarian. In the Meiji period, Japan completed their transition from an agricultural society to an industrial society. With an increasing number of jobs, the social demand for technical personnel was increasing. However, the number of talents trained by traditional apprenticeship was limited, and the training cycle was long, which could not meet this urgent requirement. In this context, the factory apprenticeship began to be led by the government, using a rapid way to cultivate cheap labor, which was the beginning of Japanese vocational education, but also the embryonic form of the modern apprenticeship. [8]

The apprenticeship system enabled rapid growth in the number of apprentices and high learning efficiency. Under the leadership of the master, students could quickly learn professional skills and apply them in use. Compared with school education, apprenticeship was more efficient and had a shorter learning time, enabling students to quickly learn the skills needed in industrial production, greatly improving work efficiency. Apprenticeships promoted the output efficiency of the Northeastern industry. The theory and practice of this teaching model made a huge contribution to the 
substantial increase in industrial output during the Puppet Manchukuo era.

\section{INDUSTRIAL DEVELOPMENT OF NORTHEAST CHINA AFTER 1949}

Since the establishment of the People's Republic of China in 1949, the industry and agriculture of Northeast China recovered rapidly. The three northeastern provinces were located in the northeastern part of the country. They are neighboring strong industrial countries, and their sea lines facilitated border trade and maritime trade. With geographical advantages, Northeast China achieved rapid development in scale and production capacity. In addition to the early liberation of Northeast China and its closeness to the Far East of the Soviet Union, it was also advanced in both industry and agriculture, which had experienced secondary and higher education during the period of Puppet Manchuria. The Northeast region absorbed and digested its industrial heritage, quickly restoring and developing its production capacity after the war, laying the foundations for human resources. At that time, there was no such situation in other parts of China. In addition, the geographical advantages of the Northeast in terms of energy and agricultural production, as well as the relatively safe geographical conditions in the early days of the founding of the People's Republic of China, combine to give the Northeast an extremely important industrial and agricultural status. It became an important production base for China's industrial construction at that time. The function of the Northeastern industry made contributions to China and has also left a strong influence on the following generations.

During the first five years from 1949 to 1955 , the three Northeastern provinces, as the bases of China's industrial raw materials and heavy equipment with excellent natural geographical conditions, strong industrial foundations and sufficient talent reserves, have supported and led the progress of China's industrialization. The Northeast Old Industrial Base is an industrial base with heavy industry as its main feature. In order to realize industrialization and establish a complete industrial system in the early 1950s, the country concentrated its human, material and financial resources into the Northeast. [10] It promoted the rapid growth of the country's economy and has provided abundant tax revenues for the country's finances. The establishment of the Northeast Industrial Base drove the rapid economic growth of New China and made outstanding contributions to the country's economic development and industrialization processes, a typical enterprise that plays a prominent role in economic construction. Furthermore, it provided valuable experiences for establishing and improving the management system of industrial enterprises in the country and trained and delivered a large number of talents. They also made contributions to the growth of an agricultural country into a "world factory".

The three northeastern provinces, including Heilongjiang, Jilin and Liaoning as important heavy industrial bases, played an important role in the country's economic development. For a long time, the Northeast has been a region with a high level of industrialization in China. The Chinese Academy of Social Sciences Report on China's Industrialization Process shows that the process of industrialization in Northeast China in 1995 ranked the second among the seven major regions of the country (three northeastern provinces, Bohai Rim, Yangtze River Delta, Pearl River Delta, six central provinces, Northwest, and Southwest). [11] Specifically, the GDP of Liaoning Province accounted for nearly half of the GDP of the three northeastern provinces, and its fluctuation trend was consistent with the overall trend of the three northeastern provinces, indicating that Liaoning Province occupies a major position in the overall economy of the three northeastern provinces. [12] Amongst the three northeastern provinces, Liaoning has the largest population, and its geographical location is the southernmost. After the defeat of Japan and Germany, the northeast region became the fourth largest industrial area after the United States, the Soviet Union, and the United Kingdom. There are many factory chimneys on both sides of the Shenyang-Dalian line from Shenyang to Dalian, and the city is connected in one piece. It has become known as the world-famous "Mianchang Industrial Zone". Shenyang Tiexi District is known as the "Oriental Ruhr".

However, from the perspective of dynamic changes, during the Ninth Five-Year Plan (1996 2000) and the Tenth Five-Year Plan (2001 2005), the relative advantages of industrialization of the three northeastern provinces continued to be lost and even turned into relative disadvantages. [13] A large number of outstanding heavy industry enterprises have entered a period of decline due to various reasons. With the advent of a tide of layoffs, factories in the entire Northeast and Northeast regions have entered a downward phase. By 2005 , the degree of industrialization in the three northeastern provinces was already lower than the national average. It can be seen that after the reform and opening up, the status of the three northeastern provinces in China's economic map continued to decline. In terms of GDP share, it has fallen from $13.34 \%$ in 1978 to $9.03 \%$ in 2014. [14] In 2014, the combined GDP of the three northeastern provinces (42347.6 billion yuan) was still less than Shandong Province (50774.8 billion yuan), which ranked only no.3. [15] In recent years, the GDP growth rate of the three provinces fell behind the national average for many consecutive years, ranking at the bottom of the national growth rate list of all provinces, and the Northeast economy has been sluggish. [16] By 2020 , the per capita GDP of the three eastern provinces became the bottom of the country. 
The reasons are diverse, but the guidance of public policies is important, especially the deviation from the implementation of industrial support policies and the lack of vocational educational support. The educational model which started during the puppet Manchu period and remained strong since the founding of the country until the 1980s. However, since the "layoffs" in the Northeast at the end of the last century, a large number of local stateowned factories have been shut down and transferred; restructuring or mergers have not brought enough jobs. Although quite a few private enterprises have emerged, they cannot meet the employment needs of laid-off workers. The ensuing decline in corporate efficiency resulted in a considerable number of industrial workers and scientific research professionals with superb skills and work experience going south for employment or entrepreneurship. Between grassroots factories and vocational education institutions, the institutions that have been integrated with industry and academia for many years have received a lot of impact, and there has been a two-way decline in the level and number of teachers. There has also been a large number of reductions in the scientific research talents in universities and colleges. This phenomenon led to a continuous decline in the level of vocational education and undergraduate education in the first two decades of this century, although the admissions rate for college entrance examination and the rate of entering higher education have been rising. Even if some graduates finish schooling, their working ability is not enough to become qualified industrial workers in a short time. The old apprenticeship system has been abandoned, following with the longterm problem of 'brain drain'. It is therefore under this concern that we would find it essential to trace back the industrial development from 1932 to 1955 and thus explore the patterns of education behind the past achievement.

\section{CONCLUSION}

The status of the heavy industrial center in the Northeast region benefits from a strong reserve of industrial and technical talents and a developed education system, including higher education institutions and vocational and technical education institutions. The apprenticeship system, as a talent training model, and technical skills are passed on and carried forward through the link of "master-apprentice", existing as a form of accumulation and transmission of human knowledge and skills. Through the guidance of cultural knowledge, training of basic business skills, and ideological education for apprentices, it could promote the comprehensive and scientific development of apprenticeships, which enabled rapid growth in the number of apprentices and high learning efficiency.

Under the policies and measures taken under the puppet Manchurian period, Northeastern higher education had a few twists and turns, and its fate is very rough. The idea that the former apprenticeship system enabled rapid growth in the number of apprentices and high learning efficiency may provide some solutions to solving the issues that the current Northeast of China is facing.

\section{REFERENCES}

[1] Y. Liang. "Research on 'Manchuria Heavy Industry Development Co., Ltd." M.A. Thesis, Harbin Normal University, 2016.

[2] [10] Y. Wang. "The Comments and Analysis of Northeast Heavy Industry in early times of new Country". M.A. Thesis, Northeast Normal University. 2005.

[3] H. Qi. "The Relationship Between Textbooks of Manchukuo and Industrial Development -Focusing on The Second Phase of Manchukuo Industrial Development and New Educational System". Study of The September Eighteenth, 1(2016) :151-164.

[4] C. Li. "Research on Higher Education During the colonized Northeast China". Thesis. Harbin Normal University, 2018.

[5] X. Yang. Research and Prospect of rural education in Modern Northeast China, History and Geographic of Northeast China, 2009, Vol 3, 85-89.

[6] [12] Z. Xu. "The Commentary of Heilongjiang Higher Education During the Period of the Republic of China." D.Phil. thesis, University of Jilin, 2013.

[7] Y. Xin. "Research on Factory Apprenticeship Law and Factory Regulations in the Republic of China". Thesis, Tianjin University of Technology and Education. 2019

[8] J. Yang. An analysis of the influence of the Japanese puppet regime on school education in Northeast China, Historiography monthly, 2004 (05): pp125128.

[9] [11] L. Chen. "A comparative study of Japan's colonial control policies towards Puppet Manchuria and Taiwan” M.A. Thesis, Yanbian University, 2015.

[13] Y. Yan. "On the System and Mechanism Reform of Government Management in Northeast Old Industrial Base." DPhil. Thesis. Jilin University of China, 2018.

[14] Y. Cao. "Research on innovation and entrepreneurship education in Colleges and Universities under the transformation of economic development mode - Taking Jilin Province as an Example." DPhil. Thesis. Northeast Normal University, 2014. 
[15] Data: National Bureau of Statistics of China. https://data.stats.gov.cn/english/easyquery.htm?cn= E0103 (accessed on 28th February 2021).

[16] W. Gao. "A Research on The Effect of Entrepreneurship Policy on City Entrepreneurship Output.” DPhil. Thesis. Tshinghua University, 2018. 